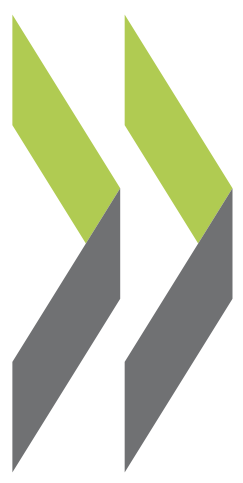

PEB Exchange, Programme on Educational Building 1998/06

\author{
Ice Storm: Reacting \\ to a Natural Disaster \\ in Quebec
}


dents from the disaster-struck areas into their

\section{ICE STORM: REACTING TO A NATURAL DISASTER IN QUEBEC}

When a severe freeze hit Q uebec in January 1998, schools and universities were forced to remain closed for up to 23 days. Here is an account of how school authorities handled the crisis and the lessons they learned.

\section{The situation}

In early January, an ice storm paralysed much of Quebec and knocked out the Hydro-Quebec power plant leaving every educational facility in six regions of Canada without electricity, and preventing 440000 students from attending school. Unlike other disasters such as explosions or earthquakes, not all of the consequences of the freeze were immediate, which made decisiontaking extremely complicated.

\section{Initial reaction}

6 An assessment was needed of the consequences of the disaster on the educational system. The $M$ inistry of Education's regional office in the worst hit area, Monteregie, undertook to contact local education authorities who in turn contacted their schools' administrations to determine the state of their facilities and the number being requisitioned by civil authorities for public shelters or for use by the armed services. This task proved quite difficult as the majority of those individuals were victims of the disaster themselves. However within a matter a days, pertinent information concerning institutions at all levels of education from pre-schools to universities was centralised and thereafter provided to the public on an almost daily basis.

Under the direction of Ms. Pauline M arois, the Ministry of Education and the Ministry of Families and Childhood (ministère de la Famille et de l'Enfance) jointly set up a help centre which provided activities for youth, financed by the Red Cross, and advice to community leaders.

At the request of the Ministry of Education, schools in regions not affected by the freeze offered to welcome stuclassrooms. For the most part however this possibility was not taken advantage of, as parents preferred not to be separated from their children.

Throughout the storm local education authorities were encouraged to consult structural experts to ensure building security, paying special attention to roofs under the weight of ice. On 19 anuary, the Ministry of Education announced plans to maintain salaries and insure compensation for material damage resulting from the freeze. Forms were sent to the local authorities asking for details of expenses incurred, and the M inistry then began analysing each claim. Of the 1800 educational buildings in the area which was hit by the freeze, claims relating to 1046 of them were soon returned, for a total of 38.1 million Canadian dollars.

\section{Making up for lost time}

The freeze had begun while many schools and universities were closed for the end-of-the-year holidays. As the crisis continued, the institutions were unable to reopen as scheduled. For pre-schools, elementary schools and high schools, local education authorities worked with teachers' unions and employee representatives to find ways to make up

the missed time without cutting into the spring holidays, because many families had already planned their vacations and it was agreed that the break would be
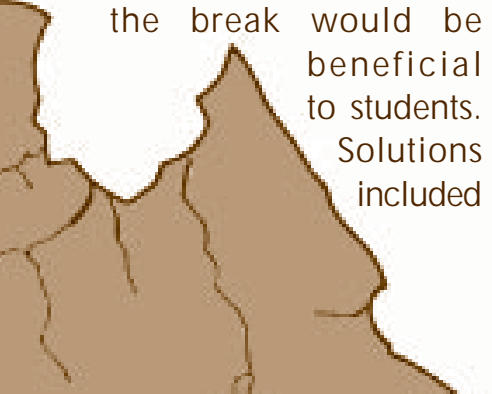
adding an hour of class at lunch time or after school, cancelling outings or festivals and lightening requirements for certain courses.

Colleges and universities showed flexibility in adapting their schedules by advancing deadlines such as cut-off dates for dropping classes. Most colleges affected by the ice storm made up lost class time by using the spring break. Universities encouraged students and professors to work out together how to make up the lost time: some held class on holidays and Sundays, others extended the length of classes from 60 to $75 \mathrm{~min}$ utes. $\mathrm{N}$ ine of the fourteen universities hit were successful in finishing on the scheduled date; the remainder closed a week late.

\section{Lessons learned}

- While many employees were prevented from reporting to work, others were counted on to provide invaluable help in handling the unusual circumstances. In Canada, human resource management of educational institutions is the responsibility of local education authorities, but the Ministry of Education offered advice as well as technical and financial support where necessary to resolve questions related to work missed during the crisis. There existed no system for compensating people whose services were required by the city or civil authorities in a time of emergency, and this resulted in unfair discrepancies in pay. The Ministry of Education recognised the need to prepare compensation guidelines for such circumstances.

- The Ministry also learned the importance of keeping updated personal address lists of their local education authorities, in the event a crisis prevents contacting them at their place of work.

- The school buildings, centrally located and structurally sound, made for safe shelters for the population. Being public buildings they are subject to national building codes, and the Ministry of Education will take an active part in the next revision of those codes.

- Whenever school facilities are requisitioned in the future, the Ministry of Education should be part of any governing bodies involved. It was not invited until well into this crisis to be represented on the Intersectorial and Interministerial Committee (comité de coordination intersectoriel et interministériel), which translated into a lack of coordination between authorities. $\mathrm{H}$ ad the $\mathrm{M}$ inistry been given immediate access to all available information such as $\mathrm{Hy}$ dro-Q uebec's schedule for restoring electricity, schools could have prepared for starting classes and rumors would have been reduced. This would also have allowed for the school system and civil authorities to be aware of each other's needs and handle the most urgent ones more quickly.

- Practicing an attitude of transparency proved to contribute to mutual confidence between the Ministry of Education and the school network. It is a policy they will continue to promote.

A detailed account by the M inistry of Education of the events of January and the following months underlines the solidarity, ingenuity and goodwill demonstrated by the numerous individuals who provided their help during the crisis.

The report, published in May 1998, is available in French through the Ministry. Contact:

M. Romeo Lajoie

Directeur des équipements scolaires

Ministère de l'éducation

1035, rue De La Chevrotière

Q uebec G 1R 5A5

Canada

Tel.: 1418644 2525,

Fax: 1418643 9224,

E-mail: romeo.lajoie@meq.gouv.qc.ca. 
SURPLUS PLACES
IN UK SCHOOLS

School Standards M inister Estelle M orris is addressing the problem of schools that have more places than they have students. In January 1997, there were approximately 774000 surplus places in primary and secondary schools in the U nited Kingdom, just under ten per cent of the total capacity. Some 2700 schools had a surplus of 25 per cent or more.

At the same time, other schools cannot meet demand in a country where parents have the choice of where to send their children. When the M inister published these figures earlier this year concern was expressed for improving parental choice and boosting standards:

"The focus of all our policies is raising standards. Surplus school places represent a poor use of resources, particularly where schools with surplus places are performing poorly or where parental preference is not being met elsewhere in the authority.

"The supply of and demand for places must be brought more closely into balance so that parental preference can be maximised and that good quality education can be provided in the most cost-effective manner. The Audit Commission has drawn attention to this issue and, with DistrictAuditors, is promoting good practice."

It is widely recognised that maintaining a higher than necessary level of surplus places wastes resources. Rationalisation offers the prospect of stronger institutions, which provide better education for pupils. N ot all these places, how ever, are removable. Some empty places are needed to allow for pupil growth, particularly in the secondary sector where the number of pupils is expected to increase by 8.7 per cent over the next five years. In the primary sector, places may be required as plans are carried out to reduce infant classes to a maximum of 30 pupils. Maintaining capacity to secure accessibility to schools in rural areas and to meet parental preference for places reduces the possibility of surplus place removal.

Trading Places, published by the Audit Commission, focuses on the issues of surplus places. The national report makes a number of recommendations for central and local governments and has been followed up by District Audit studies in each local education authority (LEA) area. It suggests that whilst LEAs might aim for school occupancy levels of between 85 percent and 105 percent of capacity , priority action should focus on schools with 25percent or more places unfilled. The report concludes that as much as 40 percent of unfilled places might be removable over a period of time but understates the difficulties involved.

Some of the measures in the recent School Standards and Framew ork Act give effect to recommendations in Trading Places and should facilitate progress towards increasing the rate of removal. Relatively easier removals have now taken place leaving only those that are politically difficult, as is almost inevitably the case with school closures, or technically difficult, because only parts of school buildings can be removed.

Schemes must also be considered for their cost effectiveness. The capital costs of implementing proposals must be measured against recurrent savings to establish whether removal of surplus places is worthwhile. The following calculation can assist LEAs in assessing cost effectiveness:

\section{$100 \times$ Recurrent Savings per Year $\div$ (Total Gross Capital Costs - Capital Receipts) $=$ Percentage Rate of Return}

The recurrent savings in the above test should be based on real and anticipated savings at current prices averaged over five years and include all premisesrelated costs such as maintenance, cleaning, insurance, heating and lighting. G ross costs are the capital costs of implementing the proposals and should include fees and value-added tax, when appropriate.

Consistent with the School Standards and Framew ork Act and Trading Places, the Minister is particularly attentive to schools with surplus whose educational performance is a cause for concern and those where high surplus is matched by pressure for places in neighbouring schools. W hilst this approach focuses on educational benefits, there is a clear capital cost whose effectiveness will not so readily be measured in terms of recurrent savings.

For more information, please contact:

Graham Lee

Architects \& Building Branch

D fEE, Caxton House

6-12 Tothill Street, London SW 1H 9N F

United Kingdom

Tel: 44171273 6709, Fax: 44171273 6762,

E-mail: Graham.Lee@dfee.gov.uk. 